\title{
Biodiesel induced corrosion and degradation: Review
}

\section{Biyodizel kaynaklı korozyon ve bozunma: Bir inceleme}

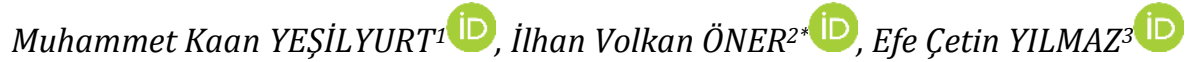 \\ 1,2,3Department of Electric and Energy, Pasinler Vocational School, Ataturk University, Erzurum, Turkey. \\ kaan.yesilyurt@atauni.edu.tr, ivoner@atauni.edu.tr, efeyilmaz@atauni.edu.tr
}

Received/Geliș Tarihi: 02.10.2017, Accepted/Kabul Tarihi: 17.05.2018

doi: $10.5505 /$ pajes.2018.01885

* Corresponding author/Yazıșllan Yazar

Review Article/Derleme Makalesi

\begin{abstract}
Rapid depletion of fossil fuel resources as well as concerns for foreign dependence in meeting energy needs have led researches for alternative fuels. Biodiesel, which can be obtained from many renewable resources such as vegetable oil and animal fat through transesterification, is the most attractive alternative fuel for cars, especially for being environmentally friendly. However, there are some cons, too. The presence of water and free fatty acids in the biodiesel makes it more corrosive than petrol-diesel, and this is an undesired feature. Corrosion induced by contact with biodiesel both reduces the life of metal parts and deteriorates the fuel properties, hence adversely affects engine performance. Therefore, the corrosive characteristics of biodiesel are very important for long term durability of engine components. In this study, we tried to investigate the corrosive effects of biodiesel and blends on engine parts by evaluating and comparing test results from earlier studies for different periods at different temperatures with different biodiesel fuels. Remedial measures to inhibit or mitigate corrosive effects of biodiesel by using additives are also tackled.
\end{abstract}

Keywords: Biodiesel, Corrosion characteristics of biodiesel, Corrosion resistance of metals, Inhibitory effects
Öz

Fosil yakıt kaynaklarının hızla tüketilmesi ve enerji ihtiyacının karșılanmasında dıșa bağımlılık kaygısı, alternatif yakıt araştırmalarına yol açmıştır. Transesterifikasyon yoluyla bitkisel yağ ve hayvansal yağ gibi birçok yenilenebilir kaynağından elde edilebilen biyodizel, otomobiller için, özellikle çevre dostu olmak için en çekici alternatif yakıttır. Ancak bazı eksiler de var. Biyodizelde su ve serbest yağ asitleri varlığı onu petrol türevi dizelden daha korozif yapar ve bu istenmeyen bir özelliktir. Biyodizel ile temastan kaynaklanan korozyon hem metal parçaların ömrünü azaltır hem de yakıt özelliklerini kötüleștirir ve bu nedenle motor performansını olumsuz olarak etkiler. $\mathrm{Bu}$ nedenle, biyodizelin korozif özellikleri, motor bileșenlerinin uzun süreli dayanıkllığı için çok önemlidir. Bu çalışmada, farklı biyodizel yakıtlarıyla farklı sıcaklıklarda farklı dönemler için önceki çalıșmaların test sonuçlarını değerlendirerek ve karşslaştırarak biyodizel ve harmanların motor parçaları üzerindeki korozif etkileri araștırılmıștır. Katkı maddeleri kullanarak biyodizelin korozif etkilerini önlemek veya azaltmak için düzeltici önlemler de ele alınmaktadır.

Anahtar kelimeler: Biyodizel, Biyodizelin korozyon karakteristikleri, Metallerin korozyon direnci, Önleyici etkiler

\section{Introduction}

The total emission by vehicles, which make up $20 \%$ world's total energy supply, is one of the main factors that pollute the air. As a result, interest to identify environmentally friendly alternative fuels has aroused. Researches indicated bio-oil, such as oil seed crops, as exploitable renewable energy that can replace fossil fuel products [1]. Biodiesel, which is also known as Fatty Acid Methyl Ester (FAME), is typically produced from vegetable oil and animal fat through transesterification [2], which can be carried out chemically or enzymatically [3].

Today, biodiesel, physical and chemical properties of which is almost analogues with petrol diesel, is considered as a good alternative to petrol-diesel. It seems to be a realistic fuel for future; as it can be used in any diesel engine without any modification [3]. In its pure form, biodiesel is considered chemically stable, but during storage, transportation and utilization, it degrades through moisture absorption, microbial oxidation, and other contaminants such as condensed water, which is one of the main corrosion factors [4].

Since biodiesel is comprised of saturated and unsaturated fatty acids, it is quite susceptible to oxidation over time. Moreover, the corrosive ions that the water contains promote microbial growth and may hydrolyze the methyl esters to produce more corrosive fatty acids at the biodiesel/water interface. As a result of oxidation, insoluble gums, and deposits and other secondary oxidation products, such as lower molecular organic acids, aldehydes and ketones, which increase the total acidity and hence the corrosiveness, [5] are formed. Besides, because of production imperfections, free water content remains within the biodiesel. These adversely affect the fuel properties and corrode vital fuel system components such as injector pumps, fuel tubes and engine parts as well as fuel delivery system components, besides causing harder starting and less power and more smoke generation [3]. All these are indeed undesired outcomes. What makes biodiesel more hostile to automotive parts than petro-diesel is attributed to the fatty acid composition and hygroscopic characteristic it has or to the residual impurities [6]-[10].

Corrosive effects of free water content and free fatty acids contained in the biodiesel on engine parts have to be minimized and/or biodiesel production procedure has to be improved in order to reduce such content. By investigating the corrosive behaviors of biodiesel, negative effects of biodiesel may be reduced or resistance of metal parts to these effects may be improved.

In order to achieve this, corrosive effects of various biodiesel types and their blends on various metals used in engine parts and fuel system have to be determined at first. In recent studies the most used biodiesel, for its fair fuel properties, is generally palm biodiesel, and among the metals mostly studied on are; aluminum, stainless steel, mild steel (low carbon steel), cast iron, copper and copper alloys such as bronze.

In addition, studies focused on determination of materials having catalyzing or inhibitory effects on biodiesel incurred corrosion have been carried out as well. As a result of 
experimental studies focused on this aspect, copper has been found to have a strong catalyst effect while stainless steel acts mostly as an inhibitor. Geller et al. (2008), supporting this finding, have reported that copper-based alloys are more prone to corrosion than iron-based alloys. However, both metals were also observed to have changed the fuel properties of biodiesel [11],[12].

Counting on the fact that metals and metal alloys used in manufacture of engine parts and fuel system components are limited and chosen not only for their corrosion resistance to fuels (biodiesel in particular) but mostly for many other properties they possess; the determination of corrosion behaviors of biodiesel, mainly governed by properties of these metals, are important to some extent only. And as current studies report neither of aforementioned metals are resistant to corrosion enough to exhibit a long term durability to be used with biodiesel. Therefore, further investigation on inhibition of corrosion mechanism is also required.

In an internal combustion (IC) engine system the fuel comes into contact with the parts and materials listed in Table 1 . Any alternative fuel an IC engine would run on should exhibit satisfactory compatibility with materials of relevant parts in question. The main objective of this study is to outline main findings of studies focused on determining corrosion behavior of biodiesel and effects on materials that are mostly used in engines and fuel delivery systems.

In Figure 1, a typical fuel delivery system of a diesel engine is illustrated with common materials used in fabrication of the fuel system parts.

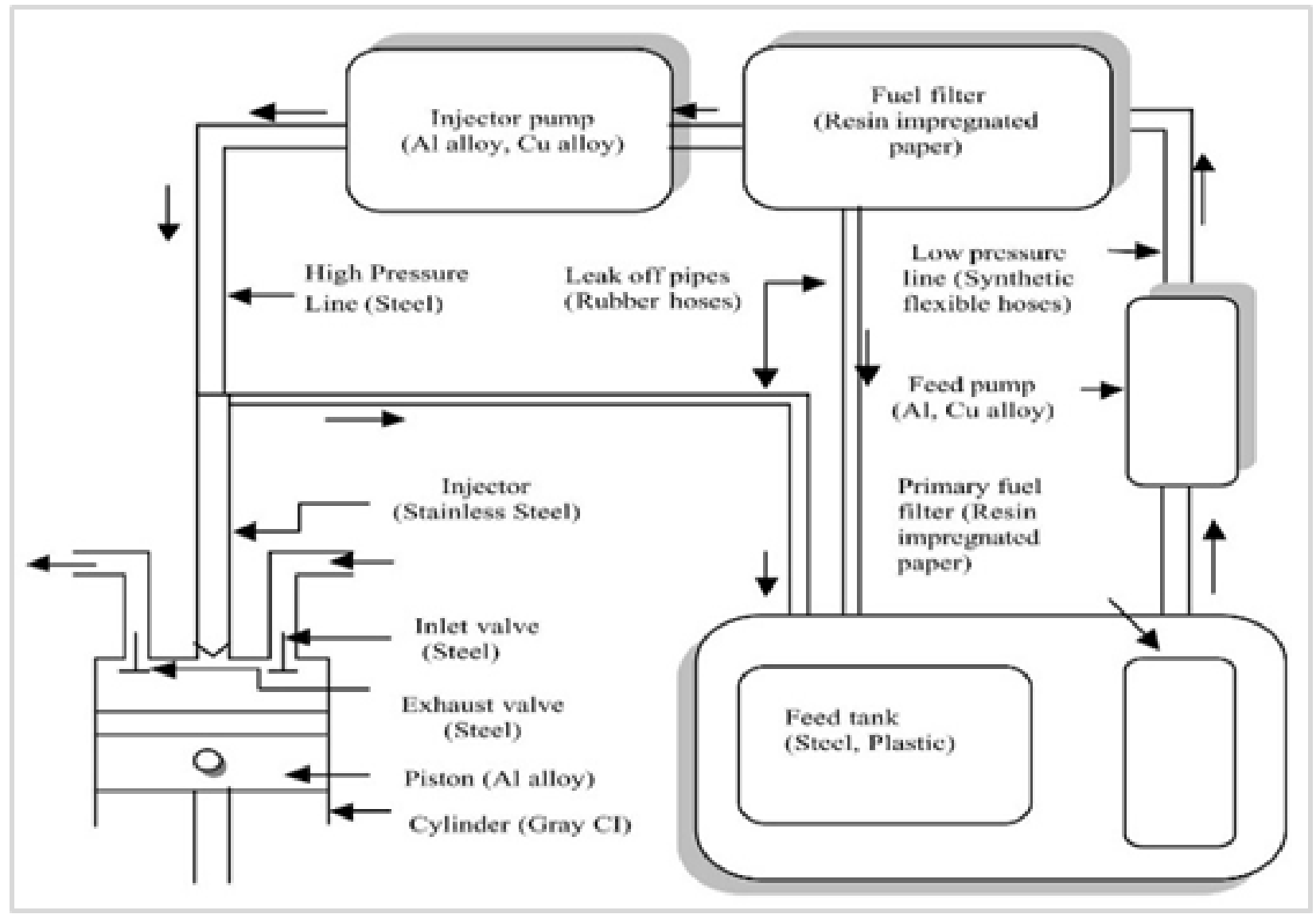

Figure 1: A Typical fuel system of a compression ignition (Diesel) engine and common materials thereof [13].

Table 1: Engine and fuel supply system components and respective materials used in their manufacture (based on [2],[13]).

\begin{tabular}{cc}
\hline Parts & Materials \\
\hline Fuel tank & Steel or plastic \\
Fuel feed pump & Aluminum alloy, iron-based alloy, copper-based alloy \\
Fuel lines and hoses & Steel, plastic, rubber \\
Fuel filter & Aluminum, plastic, paper, resin impregnated paper \\
Nozzles / bearings & Steel / White metal, leaded bronze \\
Gaskets & Elastomer, paper, cork, copper \\
Fuel pump & Aluminum alloy, iron-based alloy, copper-based alloy \\
Fuel injector / Valves & Stainless steel / Special alloy steels \\
Pistons / Piston liners & Cast iron, steel, aluminum alloy / Cast iron, nickel alloy steel \\
\hline
\end{tabular}




\section{Method}

There are two outcomes of a biodiesel induced corrosion; the first is the deterioration in fuel properties of biodiesel and the second is the degradation and corrosion of engine parts or fuel delivery system components. In order to tackle with both aspects, a long-period contact of biodiesel with relevant materials at a certain temperature is needed, and this is obtained by static immersion tests.

If a study is focused on deterioration of fuel properties; studies may be carried out experimentally on model combustion systems in laboratory scale or using real engines to test the properties of exposed fuel. If the study is focused on the corrosive effects of biodiesel on exposed materials and their degradation or corrosion, then methods diversify according to the intended aspect and how detailed and information is required. Standard Practice for Laboratory Immersion Corrosion Testing of Metals are governed by American code ASTM G31-72(2004). Methods are taken or adopted from this code [14],[15].

The nature and extent of corrosion are determined by analyzing the surfaces of certain metal strips or coupons and even visual inspections can give an idea about how corrosive a biodiesel blend is or how prone a material is to corrosion. General surface evaluation methods include optical scanning, scanning electron microscope or atomic force microscopy. On the other hand, weight loss calculation after static immersion test, electrochemical techniques with the aid of electrochemical impedance spectroscopy or on Potentiostat/Galvanostat are among general methods for corrosion measurement.

Further investigations can be carried out with Fourier Transform Infrared (FTIR) Spectroscopy to reveal more detailed information about the surface such as formation of secondary products due to degradation. Furthermore, using Energy Dispersive Spectroscopy/Energy Dispersive X-Ray Spectroscopy (EDS/EDX), the change in the atomic concentration can also be examined. Examinations carried out using X-ray diffractometers have shown formation of a second phase on metal strips subject to biodiesel and biodiesel-diesel blends.

\section{Experimental studies}

Dissolution of oxygen from the atmosphere into the biodiesel is another detrimental agent. The removal of dissolved oxygen in biodiesel have been put forward as a solution for reducing the corrosive effects of biodiesel. Using oxidized biodiesel and pure biodiesel, experiments have shown that oxidized biodiesel has an adverse effect on copper in particular [16]. Moreover, Monyem and Gerpen (2001) has reported that despite the fact that oxidized biodiesel provided reduction in CO emissions, showed no difference in NOx emissions, besides, it was observed to reduce engine performance, combustion heat and thermal conductivity [17].

Fazal et al. (2010) have examined surface morphology, corrosion rate, pitting density and color changes in both diesel and palm biodiesel in his experiments using palm biodiesel and diesel with copper, aluminum and stainless; and has shown that biodiesel has more corrosive effects for all parameters [11].

$$
\text { Corrosion rate }(\mathrm{mpy})=\frac{W \times 534}{D \times t \times A}
$$

Whereas, $W$ is the weight loss in milligrams $(\mathrm{mg}), D$ is the density in grams per cubic centimeters $(\mathrm{g} / \mathrm{cm} 3), t$ is the exposure time in hours (h) and $A$ is the initial contact surface area in square inches (in2), the formula gives the corrosion rate in mils penetration per year (mpy).

$$
\text { Pitting density }=\frac{\sum_{i=1}^{n} l_{i}}{L} x 100 \%
$$

Where $n$ is the number of pits on a horizontal straight line across the optical photograph, $l$ is the length of pits overlapping with the line and $L$ is the total length of straight line.

Fazal et al. (2010) have compared surfaces of copper, aluminum and stainless steel specimens exposed to clean biodiesel at $80^{\circ} \mathrm{C}$ for 1200 hours and examined pitting density that occurs on a specific line on these surfaces. Fazal has calculated corrosion rate, using Equation 1, and pitting density formed on the surface, using Equation 2. Optical photographs and SEM images obtained are given below in Figure 2 [11].

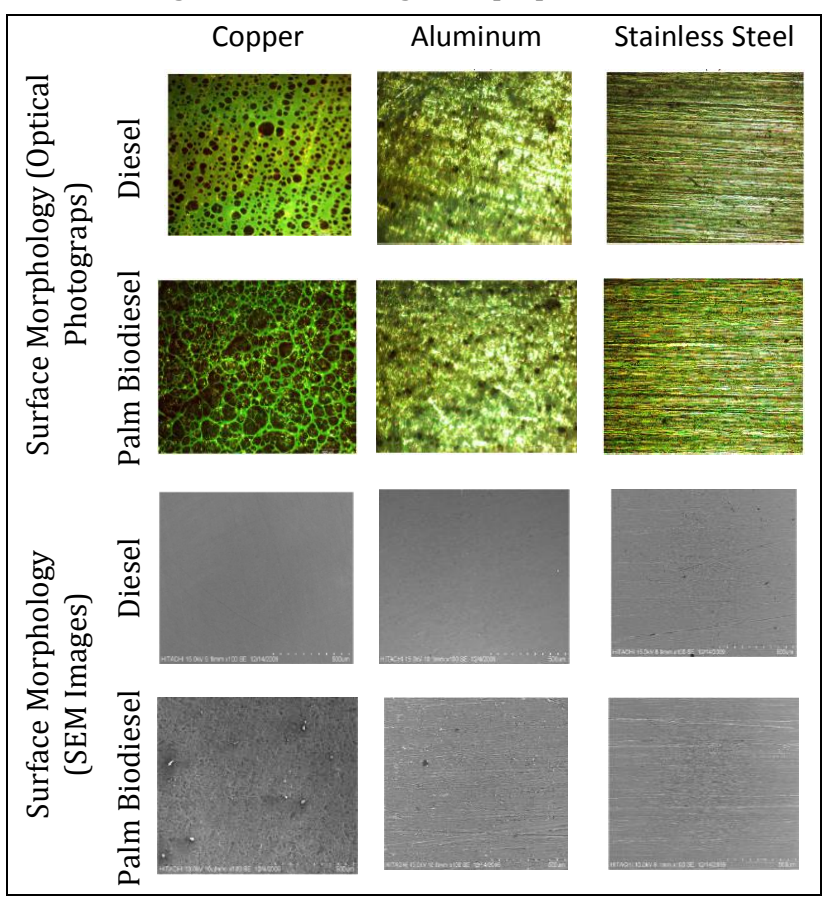

Figure 2: Effects of diesel and palm biodiesel on surface morphology of copper, aluminum and stainless steel [11].

This study, by means of mass loss measurements, corrosion rate and pitting density, has shown that biodiesel has a greater corrosive effect on copper, aluminum and stainless steel compared to diesel. In Figure 3, it can be seen that both petrodiesel and biodiesel were affected by copper the most. For petro-diesel the brownish color, which is consistent with the natural color of copper, suggests that corroded copper particles had blended into the fuel hence suspended copper particles are there in the fluid. But the green color that biodiesel has acquired upon exposure to copper is not consistent with the natural color of copper and hence suggests that other chemical reactions had taken place during exposure. We can say that copper contaminates petro-diesel but it really deteriorates biodiesel.

That is, copper has a powerful catalysis effect on oxidization of palm biodiesel. High moisture absorption, presence of oxygen and fatty acids formed due to auto-oxidation are important 
factors that increase the corrosiveness of biodiesel. Metals in contact with biodiesel cause a significant deterioration in the fuel properties of biodiesel, this case is proven with Total Acid Number, fuel density and viscosity values. Yet, another recent study by Thangavelu et al. (2016) have shown that TAN figures for copper exposed to biodiesel-diesel-ethanol blends are greater than those for both mild steel and aluminum [18].
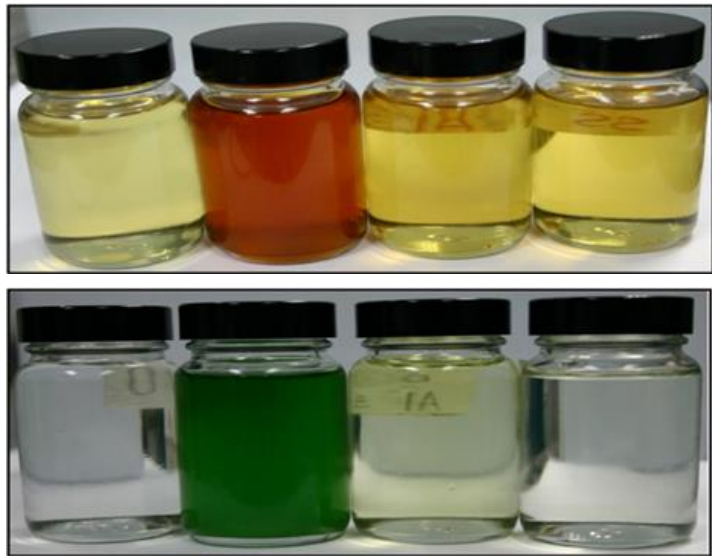

Figure 3: Color changes in pure diesel (1) and palm biodiesel (2) upon exposure to copper, aluminum and stainless steel respectively in order from left to right [11].

Although steel is more compatible for use with biodiesel, it also changes fuel properties. Color change caused in the fuel by metals are presented in Figure 4.

Singh et al. (2012) have examined the corrosion behaviors of engine parts in contact with a newly developed biodiesel and reported that biodiesel caused relatively high corrosion on copper, aluminum and copper alloys such as bronze than that caused by diesel. In the same study, stainless steel has been observed to exhibit a relatively significant corrosion resistance compared to copper and aluminum, but still to be higher compared to petroleum diesel [19].

In Figure 4, at far left is pure biodiesel-diesel-ethanol blend, and other images from left to right are the same after contact with mild steel, copper and aluminum at room temperatures and at $60{ }^{\circ} \mathrm{C}$. The color change in the fuel blend which exposed to copper is noteworthy compared to as-received state, which suggests that copper alloys such as copper carbonate $\left(\mathrm{CuCO}_{3}\right)$ had formed in biodiesel. Mild steel exhibited fairly good with very little tanning at $60{ }^{\circ} \mathrm{C}$ only probably due to the formation of iron oxides $\left(\mathrm{Fe}_{3} \mathrm{O}_{3}\right)$, while aluminum showed no color change at all [18].

Kaul et al. (2007) have investigated the corrosion behavior of biodiesel derived from seeds of Salvadora plant grown in India; they prepared $0.0366 \mathrm{dm}^{2}$ equivalent samples from metals used in engine and fuel system parts by cutting them into $15 \mathrm{~mm}$ length $\times 9 \mathrm{~mm}$ in width $\times 2 \mathrm{~mm}$ thick. They processed and polished the specimens and removed contaminants like oil and dirt by cleaning with xylene-isopropanol mixture, thereafter carried out a comparative experiment by exposing them to various biodiesel blends and commercial diesel using static immersion test method and investigated the corrosion level [20].

After preliminary measurements of prepared samples were made, at a precision of $0.1 \mathrm{mg}$, they were hung with PTFE tapes and dipped into biodiesel for 7200 hours at ambient temperature. During the experiment ambient temperature varied between the range of 15 and $40{ }^{\circ} \mathrm{C}$. Samples were cleaned using a pickling solution and re-weighed thereafter, and mass loss, corrosion rate and penetration values were calculated, which are presented in Table 2 below. Images of the samples after the test is given in Figure 5.

The findings support other studies. As can be easily seen in both images and table values, mass loss, corrosion and tarnishing have been more in samples immersed into biodiesel. The sulfur content and saturated fatty acids of $90 \%$ in the biodiesel used in this study have been concluded to have a significant effect on corrosion rate [20].

Table 2: Mass loss and corrosion rate of piston metal and piston liner metal exposed to diesel and biodiesel [20].

\begin{tabular}{ccccccc}
\hline & \multicolumn{3}{c}{ Piston metal } & \multicolumn{3}{c}{ Piston liner metal } \\
\cline { 2 - 7 } & $\begin{array}{c}\text { Mass } \\
\text { loss }\end{array}$ & \multicolumn{2}{c}{ Corrosion rate } & $\begin{array}{c}\text { Mass } \\
\text { loss }\end{array}$ & \multicolumn{2}{c}{ Corrosion rate } \\
\cline { 2 - 7 } & $\mathrm{mg}$ & $\begin{array}{c}\mathrm{mg} / \mathrm{dm}^{2} \\
\text { days }\end{array}$ & $\mathrm{mpy}$ & $\mathrm{mg}$ & $\begin{array}{c}\mathrm{mg} / \mathrm{dm}^{2} \\
\text { days }\end{array}$ & $\mathrm{mpy}$ \\
\hline $\begin{array}{c}\text { Diesel } \\
\text { Salvadora } \\
\text { Biodiesel }\end{array}$ & 0.1 & 0.0091 & 0.0058 & 0.3 & 0.0273 & 0.0065 \\
\hline
\end{tabular}

Haseeb et al. (2010), in two different experiments using static immersion test method, have investigated corrosion behaviors of copper and leaded bronze by immersing these metals into palm biodiesel, diesel and 50\%-50\% diesel-palm biodiesel blend for 2640 hours at room temperature, and for 840 hours at $60{ }^{\circ} \mathrm{C}[16]$. Figure 6 shows the corrosion rate of the samples.

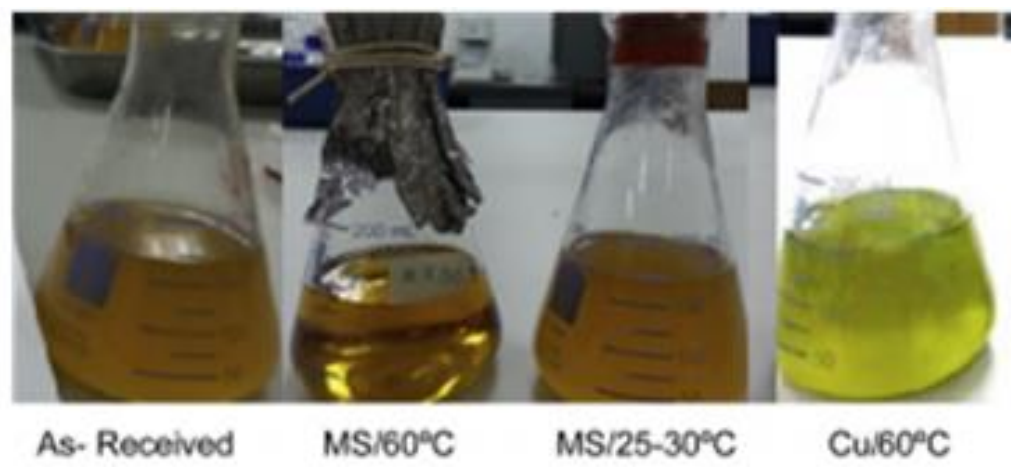

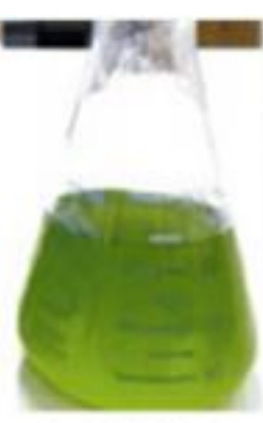

$\mathrm{Cu} / 25-30^{\circ} \mathrm{C}$

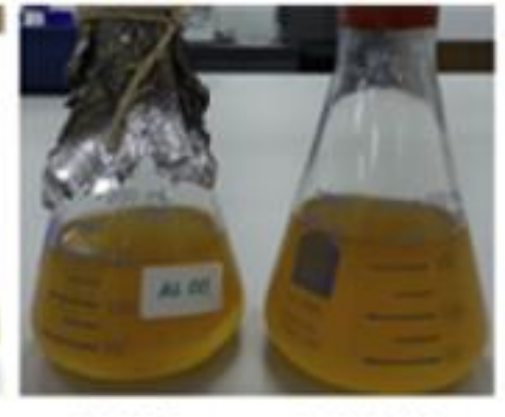

A $60^{\circ} \mathrm{C}$

AV $25-30^{\circ} \mathrm{C}$

Figure 4: Color changes in B20D70E10 fuel blend upon exposure to mild steel, copper and aluminum [18]. 


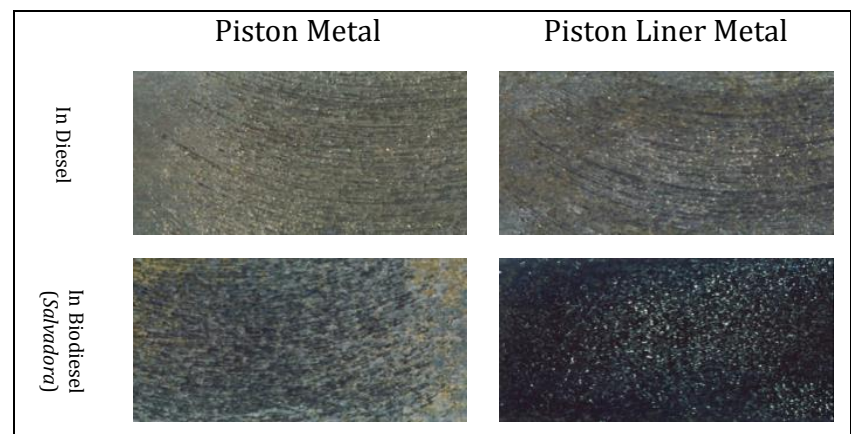

Figure 5: Corrosion of metals in diesel and biodiesel by static immersion test method [8].

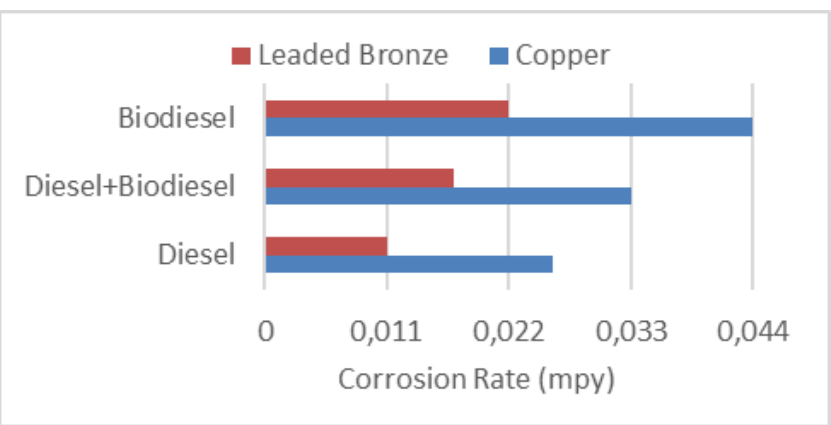

Figure 6: Corrosion rate of copper and leaded bronze at room temperature [16].

As with other static immersion test experiments, they sought to determine the corrosion rate, and corrosion behavior by examining the surface morphology and mass loss after experiments. They also have examined the fuels for the acid concentration, oxidation levels, moisture content and corrosive impurities by using various methods. As a result of the analyses they performed, corrosion resistance of copper has been shown to be much lower compared to leaded bronze.

In experiments carried out at higher temperature $\left(60^{\circ} \mathrm{C}\right)$ a higher corrosion rate is achieved and it was concluded that this situation can be explained by the fact that higher temperature improves the reaction rate and the transport of the respective elements and causes more oxygen from the atmosphere to dissolve into the fuel.

This study showed that both copper and leaded bronze have a higher rate of corrosion of biodiesel compared to diesel (Figure 7). Although leaded bronze has a lower corrosion rate than copper, either metals were subjected to significant degradation because of high acid concentration, oxidation products and free water content.

During corrosion of copper in biodiesel, first a cuprous oxide $\left(\mathrm{Cu}_{2} \mathrm{O}\right)$ (inner layer) is formed on the surface of copper in the presence of oxygen. Since $\mathrm{Cu}_{2} \mathrm{O}$ is an unstable product, it rapidly react with oxygen and turns to the stable species of $\mathrm{CuO}$, which is then reacts with $\mathrm{CO}_{2}$ and forms $\mathrm{CuCO}_{3}$ (outer layer). The formation of corrosion products during exposure are as illustrated in Figure 8. Pittings are more likely to form by replacing oxygen ions from $\mathrm{Cu}_{2} \mathrm{O}$ through destruction of $\mathrm{CuO}$ layer from copper surface [21],[22].

Haseeb et al (2010), in the same study, also investigated corrosion behaviors of biodiesel and oxidized biodiesel. They tested copper and leaded bronze samples in biodiesel and oxidized biodiesel for equal duration and observed that oxidized biodiesel is more corrosive (Figure 9), this result supports the conclusion that high fuel temperature increases corrosion rate because of increased dissolution of oxygen in the fuel [16].

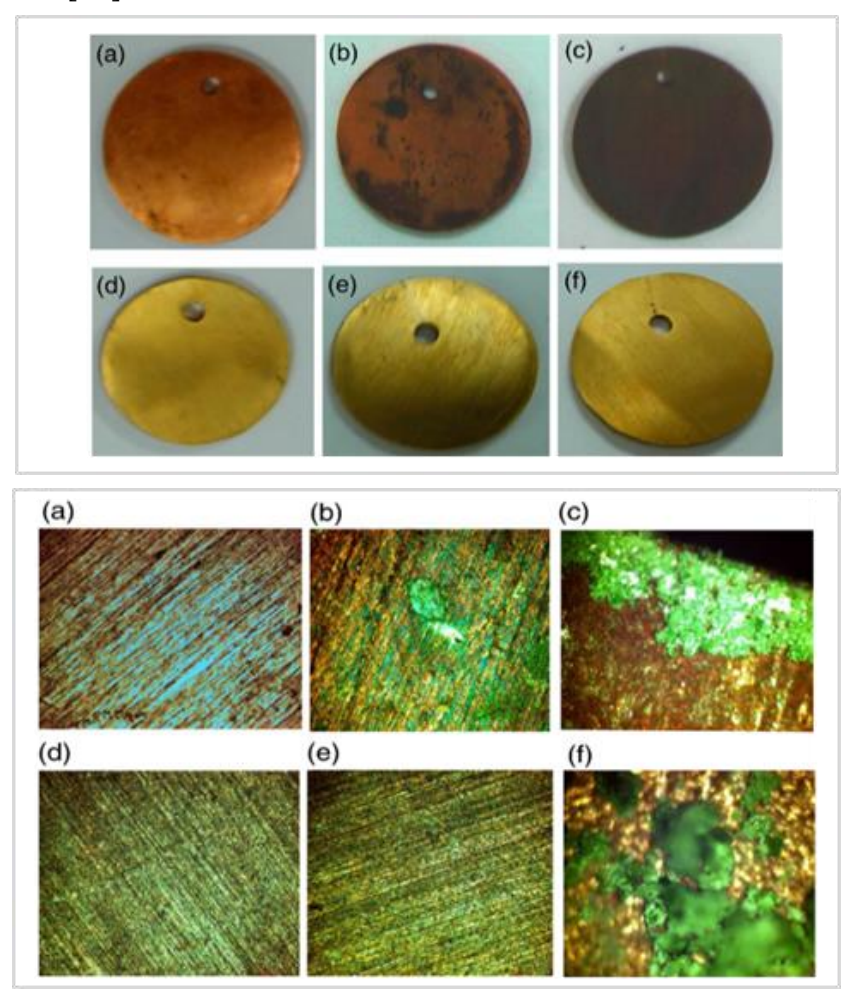

(a), (b), (c) Copper in diesel, diesel-biodiesel blend and biodiesel (d), (e), (f) bronze in diesel, diesel-biodiesel blend, and biodiesel.

Figure 7: Photos and 100X optical images of samples after the tests conducted at room temperature [16].
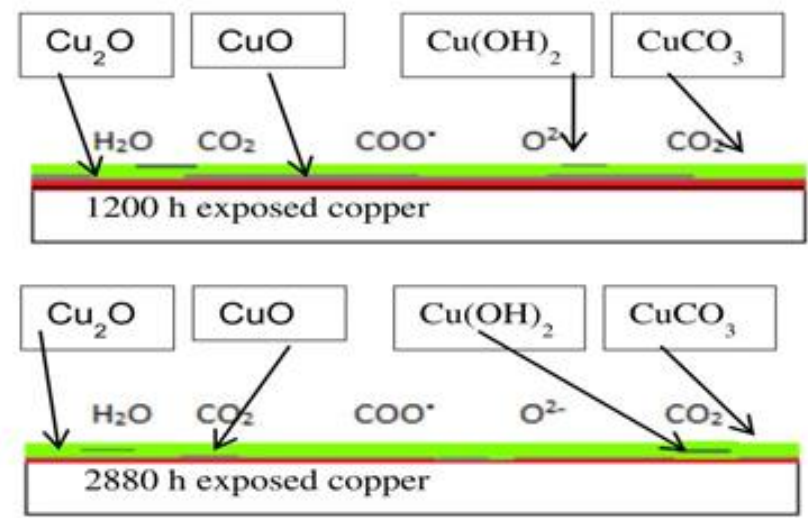

Figure 8: Formation of corrosion compounds on copper surface upon exposure to biodiesel [22].

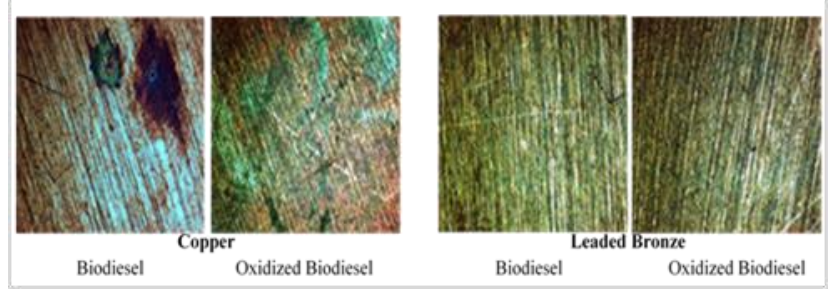

Figure 9: Corrosion of copper and leaded bronze in biodiesel and oxidized biodiesel [16]. 
Jin et al. (2015), in parallel to studies by Fazal et al. (2010) and Haseeb et al. (2010) and supporting their findings, have investigated corrosion rates on ASTM 1045 mild steel upon exposure to palm biodiesel and diesel in different ambient temperatures $\left(27,50\right.$ and $\left.80^{\circ} \mathrm{C}\right)$ for different test periods, using static immersion test method. Biodiesel, as it was for all the other studies, has caused a greater corrosion rate, but Jin has revealed that ambient temperature and exposure time have a serious effect on the corrosion rate. Corrosion on the surface has drastically increased with increasing fuel temperature. Corrosion regions were observed to be discontinuous and were scattered to the entire surface. In biodiesel, it has been observed that small pits occur randomly and at an earlier stage than they do in diesel, and increased temperature and exposure time increases the size of the surface corrosion pits faster [11],[16],[23].

Diaz-Ballote et al. (2009) investigated the corrosion behaviour of aluminium exposed to biodiesel using conventional electrochemical methods and have found that corrosion of aluminium in biodiesel contaminated with alkalis is similar to that in aqueous solutions. However, they have shown that aluminium can be used as a quantitative indicator element in determining the degree of purity of biodiesel [24].

Thangavelu et al. (2016) investigated impacts of metals on corrosion behaviour of biodiesel-diesel-etanol blends, using the same common metals and standard immersion test methods. However, they also have employed Equation 1 to calculate corrosion rate and presented a comparison table for corrosion rate of metals in biodiesel with data from similar studies from literature. They evaluated both the metal specimens and biodiesel blends and studied the effect of fuel blends on corrosion rate (CR), morphology of corrosion products, and chemical structure of metals. The colour change in biodiesel blends and surface morphology of metals were presented with optical photographs (Figure 5 and Figure 10) and FTIR spectra (Figure 11). Results, showing that the corrosion rate for mild steel is greater than aluminium but less than copper, were pretty much the same as those in other studies. As for the deterioration in fuel properties and corrosiveness, both are directly proportional to biodiesel percentage and adversely proportional to petrodiesel percentage [18].

In Figure 11, for the copper coupon, in cross comparison with Figure 8, the peaks indicate the presence of $\mathrm{CuO}$ and $\mathrm{Cu}_{2} \mathrm{O}$ and $\mathrm{Cu}(\mathrm{OH})_{2}$. Formation of carboxylate anion (COO-), suggests the film to be composed of metal carboxylate corrosion compounds, e.g. $\mathrm{CuCO}_{3}$. AS for the mild steel coupon, peaks indicate the presence of $\mathrm{Fe}_{3} \mathrm{O}_{4}$, whereas the small peaks indicate $\gamma$-FeOOH and $\alpha-\mathrm{FeOOH}$, respectively [18]

Thangavelu et al. (2016) have also verified that the change in corrosion rate is directly proportional to temperature, as they have shown that corrosion rates at $60{ }^{\circ} \mathrm{C}$ are higher than those at room temperature [18].

One another thing that needs to be taken into account along with metals is that fuel delivery systems are not comprised of metals only, therefore the compatibility of other materials including viscoelastic materials elastomers such as polymers and rubber is also important. Studies tackled with this aspect of the issue have reported that most of the elastomers which exhibited good compatibility with petrol-diesel have undergone noteworthy degradation when exposed to biodiesel. These findings are obtained using standard test methods as per relevant ASTM standards [2].

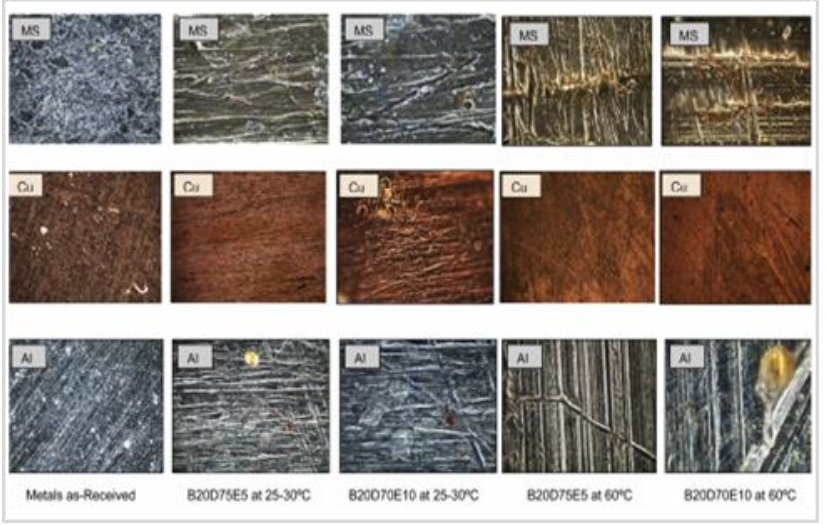

Figure 10: Optical photograph (100x) showing the morphology of corrosion products in the surface of metals after immersion at room temperature and $60^{\circ} \mathrm{C}[18]$.

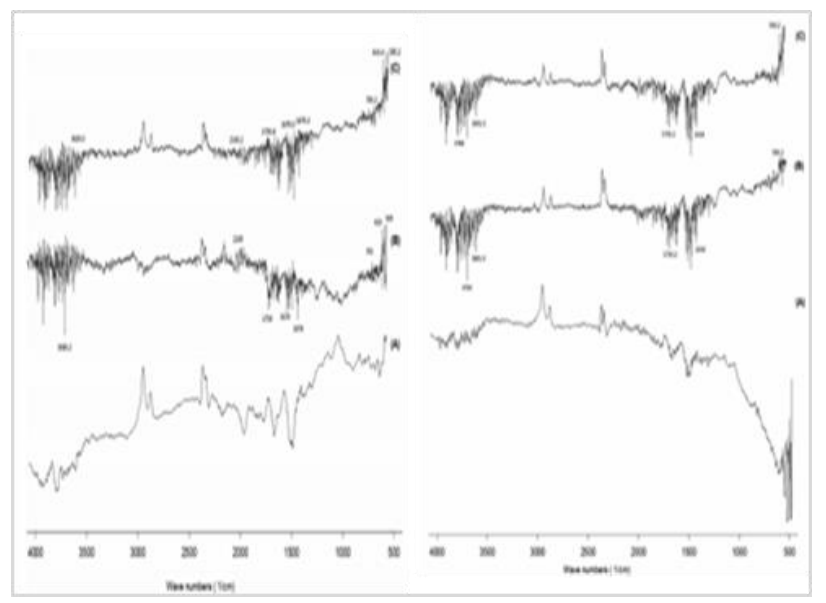

Figure 11: FTIR spectra of copper exposure to B20D70E10 fuel blend (A) before exposure; (B) after exposure at room temperature; (C) after exposure at $60^{\circ} \mathrm{C}$.

Most of the elastomeric components in the automotive fuel system is synthetic rubber because of its inherent elasticity thanks to the structure of the rubber molecule. In compression ignition engines, in which fuel be in contact with various elastomeric components, changed fuel composition and biodiesel exposure degrades gaskets, seals, elastomers and 0rings etc. While compatibility of these components with petrodiesel is recognized, their compatibility with various biodiesel fuels is still a question. As chemical compositions of biodiesels vary, their consequences on elastomers differ, too. While diesel comprises of hydrocarbons, biodiesel is a mixture of alkyl esters, which can be hydrolysed in the presence of water to form carboxylic faction. Besides, biodiesel is more prone to oxidation, especially when exposed to atmosphere. Therefore, biodiesel affect the chemical and physical properties of elastomers and cause to degrade it [25].

Aside from elastomers, Magnesium is another material that finds application fields in the automotive industry but not studied in terms of corrosion resistance to biodiesel. Magnesium is the eighth most common element. $0.13 \%$ of seawater is magnesium and it represents a virtually unlimited supply. Therefore, along with many other superior features, it is being increasingly used in the industry. As a competitive alternative to aluminum, steel and plastic, magnesium and its alloys are gathering great interest and having been developed 
for years. Year by year it gets chances of replacing conventional automotive parts. Although, actual applications of magnesium are still limited compared to major competitors steel, aluminum and plastics; and there is no known commercial uses of $\mathrm{Mg}$ in fuel system parts, it has already taken its place in the cylinder head covers [26],[27].

Considering the trending use of Magnesium, Chew et al. (2013) have compared Magnesium with its major competitor in terms of being light-weight, aluminum in palm biodiesel for 720 and 1440 hours. Their surface morphologies were reported to have shown noteworthy difference. Magnesium was covered by sticky gel-like mass, whereas aluminum remained clean, as shown in Figure 12.

In this respect, counting on the formation of gel-like mass on the surface, we can say that magnesium will deteriorate fuel properties more than aluminum, too.
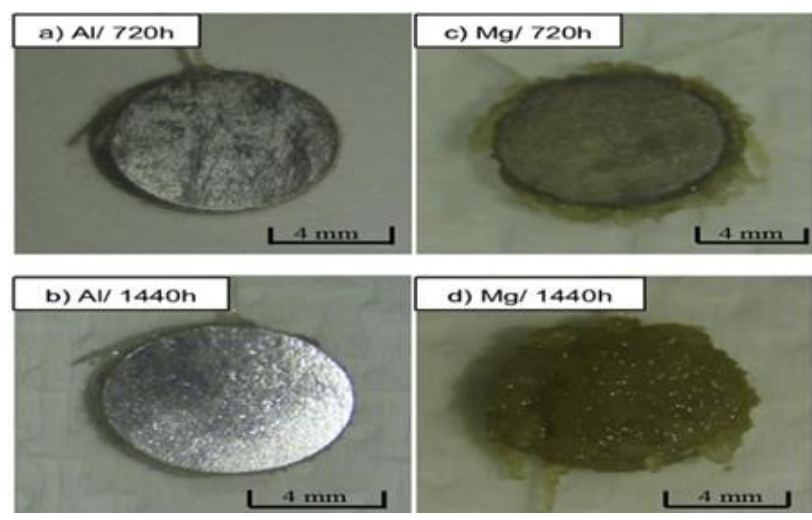

Figure 12: Optical images of aluminum and magnesium coupons exposed to biodiesel for 720 and $1140 \mathrm{~h}$ [28].

\subsection{Corrosion Inhibition and prevention}

It is clear that studies carried out by many researchers to characterize the corrosion behavior of different materials in biodiesel have proved that neat biodiesel is more corrosive than its blends and than neat petro-diesel. They also have shown that copper is much more prone to corrosion among all others. However, there has been few researches focused on remedial measures of biodiesel induced corrosion.

There are different traditional methods used for reduction or prevention of corrosion, including cathodic protection, process control, reduction or removal of impurity content, and surface treatment, as well as incorporating alloys into the subject metal. Moreover, past researches have already proven that inhibitors, which slow down the corrosion rate, are agents of easier and cheaper corrosion protection and prevention in acidic media [29]. Besides it is more applicable with regards to biodiesel.

So, the question is what could be done to remedy corrosiveness of biodiesel and answers come from researchers pioneered by Fazal. Three manin aspects that are focused on are incorporation of alloys, reduction or removal of impurity content and use of inhibitors.

Jakeria et al. investigated the behavior of copper and mild steel exposed to palm biodiesel in presence of two organic corrosion inhibitors benzotriazole and adenine in different molar concentrations (mol/L). The corrosion rates in milligrams per square centimeters after 60 days of static immersion are as given in Figure 13. Benzotriazole exhibited better performance for both the two metals and offered a better corrosion inhibition than adenine did. [30]

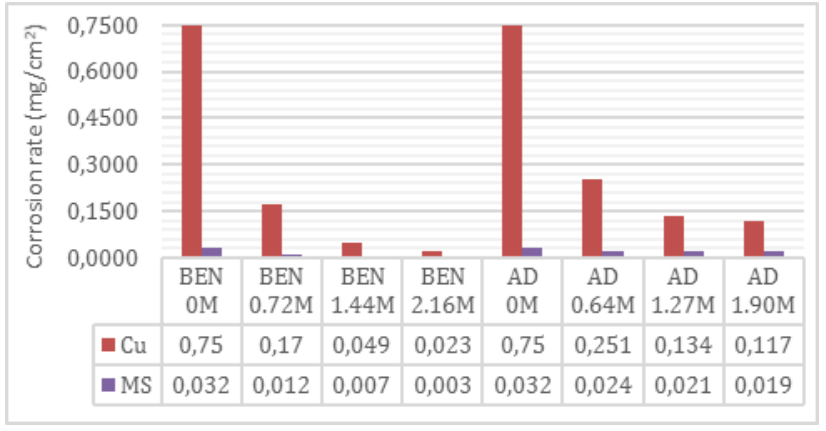

Figure 13: Effect of presence of inhibitors benzotriazole (BEN) and adenine (AD) on corrosion rate of copper and mild steel [30].

Counting on the fact that effectiveness of corrosion inhibitors would depend on their adsorption capabilities on metal surfaces, which implies the mobility of multicomponents from an adsorbate to an adsorbent as well as attachment via physical or chemical bonds; Fazal et al. (2016) picked up additives having good adsorption capabilities such as tert-butylamine (TBA), benzotriazole (BTA), butylatedhydroxytoluene (BHT), and pyrogallol (PY) to test their inhibitory effects on cast iron and low carbon steel. As it can easily be seen in

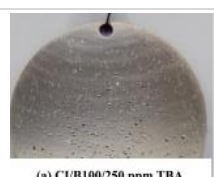

(a) CVB100250 ppm TBA

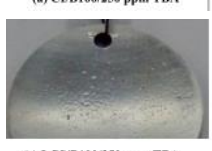

(e) $L$ CSSB100250 ppm TBA
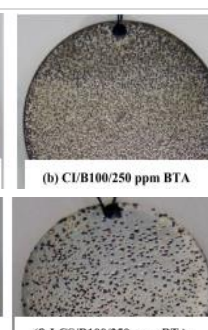
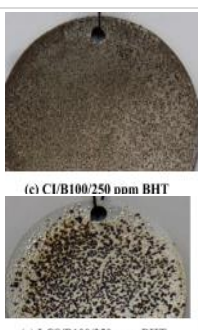

(g) LCSB1000250 ppm BHT

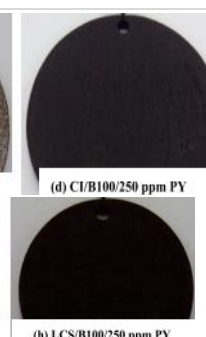

(h) 4 CSBB100250 ppm PY
Figure 14, investigations have shown that tert-butylamine (TBA) exhibited greatest inhibition with an efficiency figure of $86.54 \%$ for CI and $86.71 \%$ for LCS thanks to its physical adsorption of $\mathrm{N}$-containing compound which creates a protective layer over the metal surface and prevents corrosion [31].
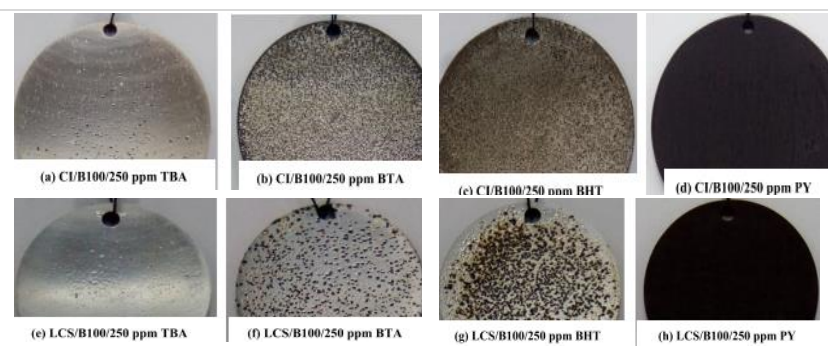

Figure 14: Appearances of cast iron (CI) and low carbon steel

(LCS) coupons exposed to neat biodiesel with different additives at room temperature [31].

İleri and Koçar (2013) have investigated the effects of antioxidant additives on a diesel engine running on canola oil. The use of antioxidants was reported to improve oxidation stability and reduce the NOx emissions of biodiesel [32]. Later Gurau et al. (2016) have investigated storage and oxidation stability of biodiesel, which is produced from bitter apricot kernel oil, stored air-tight in dark and under sunlight for six months. They used five different antioxidants, namely, tert- 
butylhydroquinone (TBHQ), butylated hydroxytoluene (BHT), butylated hydroxyanisole (BHA), pyrogallol, and propyl gallate, one at a time with varied dosage, and examined the enhancement in the induction period.

The results obtained yielded very valuable findings, such that, (a) the acid number of the biodiesel fuel changes almost by $25 \%$ depending on whether it is exposed to sunlight or not, while other properties are also affected; (b) for the same dosage, the most effective antioxidant is propyl gallate $(\mathrm{PG})$ and pyrogallol (PY) performs quite close to it; (c) by a 300 ppm dosage of antioxidants, storage and oxidation stability of biodiesel can be extended from by $20 \%$ to 1.5 times in both storage conditions. A summary of results obtained from this study is given in Figure 15. The storage stability tests by Gurau, as shown in Figure 15, show that the acid number and kinematic viscosity of biodiesel is directly proportional while the induction period is adversely proportional to the storage period. The overall effectiveness of antioxidants in descending sort is $\mathrm{PY}>\mathrm{PG}>\mathrm{BHA}>\mathrm{BHT}>\mathrm{TBHQ}$. [33].

This finding has also been verified by Fazal et al. (2017) who used pyrogallol (PY) and butylated hydro-oxy toluene (BHT) as antioxidants to investigate fuel properties, such as induction period, density, viscosity, acid number and calorific values, at room temperature for 60 days. They also reported. pyrogallol
(PY) to be more effective in suppressing the corrosion of metal surface, and deterioration of fuel composition and fuel properties [34].

Another study on the inhibition effectivemess of BHT in biodiesel blends has been conducted by Deyab (2016), who reported that increased BHT concentration decreases corrosion rate on carbon steel. This behavior is attributed to two factors; the first being the adsorption of BHT at carbon steel/biodiesel interface, which is able to adsorb on the carbon steel surface through the lone pair of electron of $\mathrm{OH}$ group, and the second, the inhibition of biodiesel oxidation by which decrease the acidity and peroxide value of biodiesel [35].

Fazal et al. (2018) investigated the sustainability of additivedoped biodiesel upon exposure of copper-based materials, namely copper, leaded bronze, phosphor bronze, in the presence of inhibitors (Benzotriazole [BTA] and Tertbutylamine [TBA) and antioxidants (Butylated hydroxytoluene [BHT], Propyl Gallate [PG] and Pyrogallol [PY)] as additives. They reported that metal surface degradation was significantly reduced in the presence of these additives. In particular, the inhibitors benzotriazole (BTA) and tertbutylamine (TBA) rather than the antioxidants improved the sustainability of biodiesel significantly by limiting metal surface degradation [36].
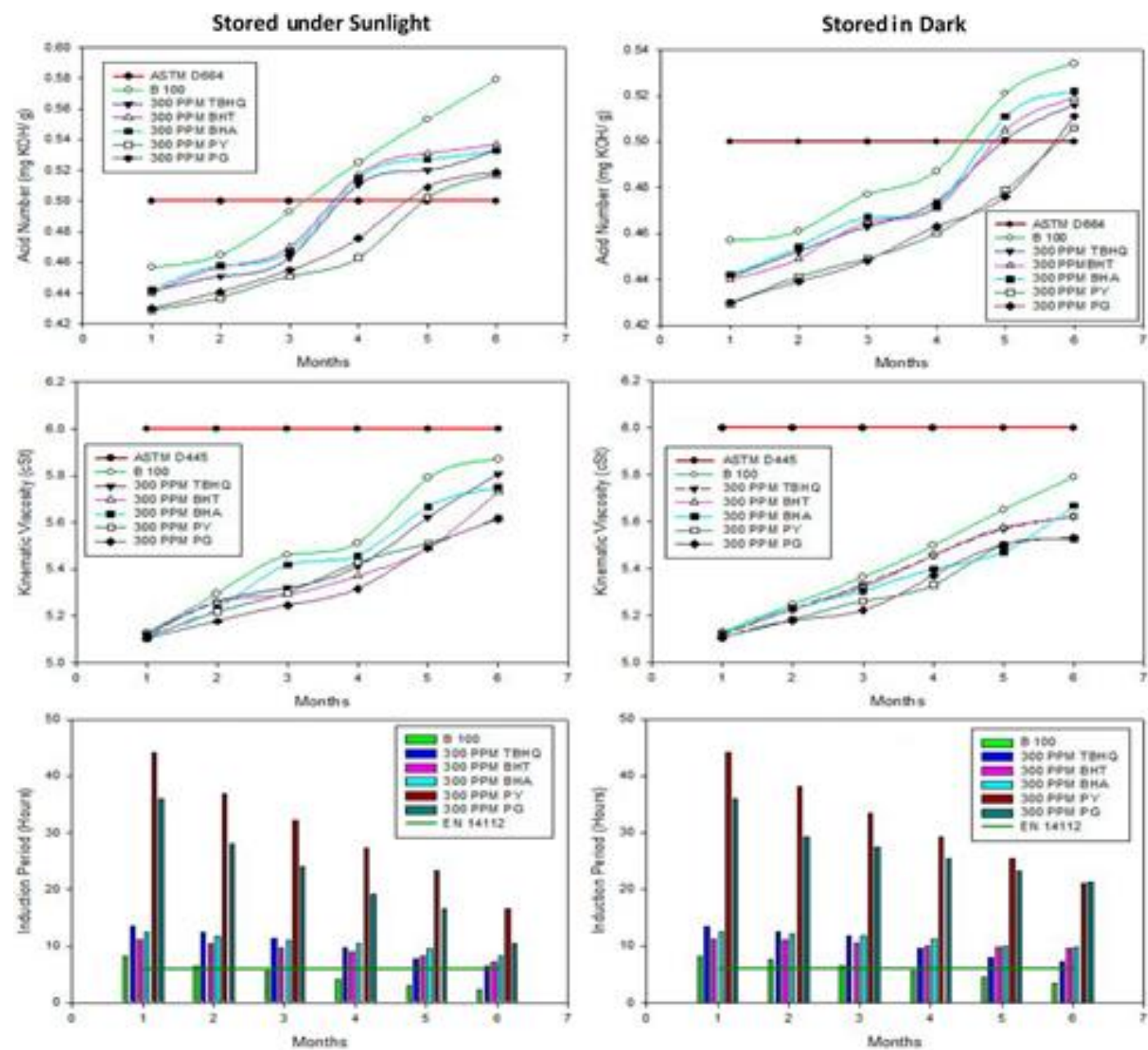

Figure 15: Induction period, kinematic viscosity and acid numbers compared for biodiesel with a dosage of 300 ppm antioxidant additives against permissible limits of relevant standards in different storage conditions [33]. 


\section{Discussion}

Referring to the research findings in literature, with increasing fuel temperature the pitting occurred on the surface increase, hence the life of the material is reduced. This situation can be explained by the introduction of a faster chemical reaction between the surface of the material and environment because of the fact that corrosive environment becomes more aggressive with the temperature rise in the environment.

Increased corrosive effect in the environment will accelerate the fatigue of materials and it will adversely affect the material life. When the studies in the literature are reviewed, it can be seen that a variety of coatings are applied to material surface in order to reduce the impact of such situations. Doing so, corrosive effects which become more effective with the rise in temperature were tried to be reduced to a minimum.

Gurau et al. (2016) tackled with oxidation and storage stability of biodiesel quite well and thoroughly but the fuel properties of antioxidant-added-biodiesel should also be tested to see how or whether the engine performance is affected. Besides it is clear from this study that, no additive in no dosage could maintain physicochemical properties of fuel in conformance with relevant standards. And with the highest dosage the stability period can only be extended by around one and a half months. Biodiesel, unlike petrol-diesel, can be produced everywhere around the world and there is no need for intercontinental or even interprovincial transportation in order to be served to the end user, therefore an extra month of stability may not be considered necessary if addition of antioxidants deteriorates the fuel properties or place a burden on the unit price of the biodiesel [33].

Another aspect of discussing research findings cited so far from recent studies is about how or whether they accurately reflect the actual conditions. A study by Chandran et al. suggests that they did not. They have set up a state of the art immersion method that simulates a real common rail diesel engine (CRDE) operation. Results obtained with this novel immersion method were compared to those, they obtained from a previous experiment carried out with standard immersion method and taken as the baseline data. Comparisons have shown that their simulated immersion test has lowered biodiesel induced corrosion on copper and degradation on nitrile rubber (NBR) materials by up to $93 \%$ and $85 \%$, respectively.

Why Chandran et al. have picked up copper as the metal, and nitrile rubber as the elastomer to investigate the behaviors of is that; they, after biodiesel exposure, are reported to be the most adversely affected metal as per ASTM G31, and the most severely affected elastomer as per ASTM D471, respectively. According to the evaluation study of material compatibility of biodiesel, the ratio of change in metal corrosion and elastomer degradation between B0 and B100 blends is found to be $9.9 \%$ and $35 \%$, respectively [37].

\section{Conclusions}

Biodiesel serves as a promising alternative in terms of biodegradability, environmental friendliness, renewability and better lubrication but using and commercializing biodiesel is hindered because of its low oxidation stability, because of which the viscosity of biodiesel is increased, engine and fuel system components are corroded, and fuel filters are plugged as a consequence of the formation of gums and sediments.
As fuel properties of biodiesel deteriorates by storage, high temperature, moisture absorption and metal contamination, its compatibility cannot be guaranteed even if the properties of asreceived biodiesel comply with the given standards. Biodiesel is hygroscopic in nature and it absorbs moisture from the atmosphere upon prolonged storage. Furthermore, at higher temperatures it gets oxidized, which further increases the free water content [38],[39].

Presence of water content, water vapor and dissolved oxygen in biodiesel as well as free fatty acids and increased temperature, as proven in all studies in the literature, adversely affects the engine performance by lowering the combustion heat of the fuel and cause increased corrosive effects on metal parts.

Biodiesel has been found to cause an adverse effect more on copper among materials used in the manufacturing of engine parts, such as copper, aluminum and stainless steel, by increasing the corrosion rate, and it is observed that copper acts as a catalyst while stainless steel, on the contrary, acts as an inhibitor. However, both metals have been found to affect the properties of fuel.

Considering that fuel temperature is a parameter for the corrosion rate as shown by Haseeb and Jing, and that fuel temperature mainly depends on the atmospheric temperature, biodiesel can be concluded to be more suitable for cold and temperate climates [16],[23].

Current permissible concentration of pure biodiesel in diesel ranges between $\mathrm{B} 2$ and $\mathrm{B} 20$ in different countries around the world. A list of current permissible rates and future targets for some countries including the US and EU has been presented by Chandran et al. (2016). Currently the maximum utilizable concentration rate is concluded to be $20 \%$ by volume for a pure biodiesel that meets the specifications declared by ASTM D6751 [Standard Specification for Biodiesel Fuel (B100) Blend Stock for Distillate Fuels], a consensus standard by American Society of Testing and Materials (ASTM), developed in cooperation with vehicle, engine, and fuel injection equipment companies; petrodiesel and biodiesel producers and distributors; and state and federal regulators and third parties through the ASTM standard development process [40].

Using any biodiesel in higher concentration level is not permissible because of strong evidences of severe metal corrosion and elastomer degradation which will indeed eventuate in noteworthy early failure fuel system components as well as engine parts. Only if the figures for the physicochemical properties of produced biodiesel is improved beyond the projected figures of mentined standard ASTM D6751, it may be considered for a rise in the concentration of biodiesel in the blend. Relying on this standard, we can assume that, the closer the figures to the standard figures the closer to B20 the concentration can be, likewise the lesser the figures the lower than B20 the concentration should be.

Considering the substantial difference in corrosion and degradation levels Chandran et al. (2016b) have achieved using their novel immersion method, we can assert that all similar studies that have used standard static immersion test to investigate corrosion behaviors of biodiesel blends are likely to have same or close difference between laboratory results and actual situation. If their immersion method is proved to reflect the actual situation better, if not the best, we may conclude that static immersion test method is not fit for purpose or findings 
from previous studies carried out using standard immersion tests should have a coefficient figure of what Chandran et al. have reported [37].

\section{References}

[1] Chandran, D. Experimental Investigation into the PhysicoChemical Properties Changes of Palm Biodiesel Under Common Rail Diesel Engine Operation for the Elucidation of Metal Corrosion and Elastomer Degradation İn Fuel Delivery System. Thesis (Ph.D.), University of Nottingham, Great Britain, 2017.

[2] Chandran D, Ng HK, Lau HLN, Gan S, Choo YM. "Investigation of the effects of palm biodiesel dissolved oxygen and conductivity on metal corrosion and elastomer degradation under novel immersion method". Applied Thermal Engineering, 104, 294-308, 2016.

[3] Demirbas A. "Progress and recent trends in biodiesel fuels". Energy Conversion and Management, 50(1), 14-34, 2009.

[4] Wang W, Jenkins PE, Ren Z. "Heterogeneous corrosion behaviour of carbon steel in water contaminated biodiesel". Corrosion Science, 53(2), 845-849, 2011.

[5] Cursaru D-L, Brănoiu G, Ramadan I, Miculescu F. "Degradation of automotive materials upon exposure to sunflower biodiesel". Industrial Crops and Products, $54,149-158,2014$.

[6] Fazal MA, Haseeb ASMA, Masjuki HH. "Effect of different corrosion inhibitors on the corrosion of cast iron in palm biodiesel”. Fuel Processing Technology, 92(11), 2154-2159, 2011.

[7] Fazal MA, Haseeb ASMA, Masjuki HH. "Effect of temperature on the corrosion behavior of mild steel upon exposure to palm biodiesel". Energy, 36(5), 3328-3334, 2011.

[8] Fazal MA, Haseeb ASMA, Masjuki HH. "Degradation of automotive materials in palm biodiesel". Energy, 40(1), 76-83, 2012.

[9] Haseeb ASMA, Fazal MA, Jahirul MI, Masjuki HH. "Compatibility of automotive materials in biodiesel: A review". Fuel, 90(3), 922-931, 2011.

[10] Hu E, Xu Y, Hu X, Pan L, Jiang S. "Corrosion behaviors of metals in biodiesel from rapeseed oil and methanol". Renewable Energy, 37(1), 371-378, 2012.

[11] Fazal MA, Haseeb ASMA, Masjuki HH. "Comparative corrosive characteristics of petroleum diesel and palm biodiesel for automotive materials". Fuel Processing Technology, 91(10), 1308-1315, 2010.

[12] Geller DP, Adams TT, Goodrum JW, Pendergrass J. “Storage stability of poultry fat and diesel fuel mixtures: Specific gravity and viscosity". Fuel, 87(1), 92-102, 2008.

[13] Sorate KA, Bhale PV. "Impact of biodiesel on fuel system materials durability”. Journal of Scientific \& Industrial Research, 72, 48-57, 2013.

[14] Boonyongmaneerat Y, Sukjamsri C, Sahapatsombut U, Saenapitak S, Sukkasi S. "Investigation of electrodeposited Ni-based coatings for biodiesel storage". Applied Energy, 88(3), 909-913, 2011

[15] J01 Committee. "Guide for Laboratory Immersion Corrosion Testing of Metals(G31-72). West Conshohocken, PA: ASTM International, 2004.

[16] Haseeb ASMA, Masjuki HH, Ann LJ, Fazal MA. "Corrosion characteristics of copper and leaded bronze in palm biodiesel". Fuel Processing Technology, 91(3), 329-334, 2010.
[17] Monyem A, van H. Gerpen J. "The effect of biodiesel oxidation on engine performance and emissions". Biomass and Bioenergy, 20(4), 317-325, 2001.

[18] Thangavelu SK, Ahmed AS, Ani FN. "Impact of metals on corrosive behavior of biodiesel-diesel-ethanol (BDE) alternative fuel". Renewable Energy, 94, 1-9, 2016.

[19] Singh B, Korstad J, Sharma YC. "A critical review on corrosion of compression ignition (CI) engine parts by biodiesel and biodiesel blends and its inhibition". Renewable and Sustainable Energy Reviews, 16(5), 34013408, 2012

[20] Kaul S, Saxena RC, Kumar A, Negi MS, Bhatnagar AK, Goyal HB, Gupta AK. "Corrosion behavior of biodiesel from seed oils of Indian origin on diesel engine parts". Fuel Processing Technology, 88(3), 303-307, 2007.

[21] Fazal MA, Haseeb ASMA, Masjuki HH. "Corrosion mechanism of copper in palm biodiesel". Corrosion Science, 67, 50-59, 2013.

[22] Norouzi S, Eslami F, Wyszynski ML, Tsolakis A. “Corrosion effects of RME in blends with ULSD on aluminium and copper". Fuel Processing Technology, 104, 204-210, 2012.

[23] Jin D, Zhou X, Wu P, Jiang L, Ge H. "Corrosion behavior of ASTM 1045 mild steel in palm biodiesel". Renewable Energy, 81, 457-463, 2015.

[24] Díaz-Ballote L, López-Sansores JF, Maldonado-López L, Garfias-Mesias LF. "Corrosion behavior of aluminum exposed to a biodiesel". Electrochemistry Communications, 11(1), 41-44, 2009.

[25] Sorate KA, Bhale PV. "Biodiesel properties and automotive system compatibility issues". Renewable and Sustainable Energy Reviews, 41, 777-798, 2015.

[26] Blawert C, Hort N, Kainer KU. "Automotive Applications of Magnesium and Its Alloys". Transactions of the Indian Institute of Metals, 57(4), 397-408, 2004.

[27] Total Materia. "Automotive Uses of Magnesium Alloys: Part One". https://www.totalmateria.com/page.aspx?ID=CheckArti cle\&LN=EN\&site $=\mathrm{ktn} \& N M=246$ (24.04.2018).

[28] Chew KV, Haseeb ASMA, Masjuki HH, Fazal MA, Gupta M. "Corrosion of magnesium and aluminum in palm biodiesel: A comparative evaluation”. Energy, 57, 478-483, 2013.

[29] Chigondo M, Chigondo F. "Recent Natural Corrosion Inhibitors for Mild Steel: An Overview". Journal of Chemistry, 2016(10), 1-7, 2016.

[30] Jakeria MR, Fazal MA, Haseeb ASMA. "Effect of corrosion inhibitors on corrosiveness of palm biodiesel". Corrosion Engineering, Science and Technology, 50(1), 56-62, 2015.

[31] Fazal MA, Sazzad BS, Haseeb ASMA, Masjuki HH. "Inhibition study of additives towards the corrosion of ferrous metal in palm biodiesel". Energy Conversion and Management, 122, 290-297, 2016.

[32] İleri E, Koçar G. "Effects of antioxidant additives on engine performance and exhaust emissions of a diesel engine fueled with canola oil methyl ester-diesel blend". Energy Conversion and Management, 76, 145-154, 2013.

[33] Gurau VS, Agarwal MS, Sarin A, Sandhu SS. "Experimental Study on Storage and Oxidation Stability of Bitter Apricot Kernel Oil Biodiesel”. Energy \& Fuels, 30(10), 8377-8385, 2016.

[34] Fazal MA, Jakeria MR, Haseeb ASMA, Rubaiee S. "Effect of antioxidants on the stability and corrosiveness of palm biodiesel upon exposure of different metals". Energy, 135, 220-226, 2017. 
[35] Deyab MA. "The inhibition activity of butylated hydroxytoluene towards corrosion of carbon steel in biodiesel blend B20". Journal of the Taiwan Institute of Chemical Engineers, 60, 369-375, 2016.

[36] Fazal MA, Suhaila NR, Haseeb ASMA, Rubaiee S. "Sustainability of additive-doped biodiesel: Analysis of its aggressiveness toward metal corrosion". Journal of Cleaner Production, 181, 508-516, 2018.

[37] Chandran D, Hoon Kiat NG, Nang HLL, Suyin G, Choo YM, Jahis S. "Compatibility of biodiesel fuel with metals and elastomers in fuel delivery system of a diesel engine". Journal of Oil Palm Research, 28(1), 64-73, 2016.

[38] Sundus F, Fazal MA, Masjuki HH. "Tribology with biodiesel: A study on enhancing biodiesel stability and its fuel properties". Renewable and Sustainable Energy Reviews, 70, 399-412, 2017.
[39] Tormin TF, Cunha RR, Richter EM, Munoz RAA. "Fast simultaneous determination of BHA and TBHQ antioxidants in biodiesel by batch injection analysis using pulsed-amperometric detection". Talanta, 99, 527-531, 2012.

[40] National Biodiesel Board (NBB). "Guidance on Blends Above B20". https://westcoastcollaborative.org/files /BBG/fleet-appendix/NBB-B20-AboveRecommend.pdf (24.04.2018) 